\title{
TRADITIONS AND INNOVATIONS IN LEGAL DISCOURSE ON THE CATEGORIES “JURISDICTION” AND “SOVEREIGN RIGHTS”
}

Fedotov O. P., Averochkina T. V.

\section{INTRODUCTION}

The current state of the development of Ukrainian legislation and legal science testifies to the rapid updating and introduction of progressive world practices and long-standing positive experience of foreign countries. In these circumstances, the importance of studying not only domestic but also foreign experience, as well as the practices used in the development and adoption of universal agreements during world and regional international forums, is actualized. In this connection, some of the legal categories that have been long drawn up and studied in Ukrainian legal science are objectively acquiring new, broader content. In particular, this applies to the current and projected legislation in the field of maritime activities, as well as to maritime law as a complex branch of law, covering the regulation of private and public law aspects of navigation. Moreover, maritime activity is one of those human activities that are most commonly subject to international legal standards, and for which such standards take effect in a simplified and sufficiently rapid manner.

In 1999 Ukraine ratified a leading international instrument governing the regime and legal status of all maritime territories - the United Nations Convention on the Law of the Sea $1982^{1}$ (UNCLOS'82). The fact of accession to this document defined all further steps of the state in the direction of development and updating of the national maritime legislation. At the same time, in UNCLOS'82 a slightly new for the national legal science view on some legal categories (in particular, the category "jurisdiction") was reflected, as well as there were used categories that are new or very briefly developed in national legal science (in particular, the "sovereign rights"). In this connection, there is a need for a scientific study of the traditions and innovations in the legal discourse on the categories of "jurisdiction" and "sovereign rights" in order to determine the directions and possibilities of updating the scientific views on them, and, as a result, to change the current legislation.

${ }^{1}$ Convention on the Law of the Sea, 1982. The official website of UN. URL: http://www.un.org/depts/los/convention_agreements/texts/unclos/ unclose.pdf. 


\section{The genesis of the legal category "jurisdiction” in legal science and legislation}

It is considered that the word "jurisdiction" ("jurisdictio") is derived from the Latin words "jus" - "right” and "dicere" - "say", "proclaim", which literally means "establishing a right" or "proclaiming a right". In ancient Rome, the word "jurisdiction" meant justice, litigation (although more closely related to this type of legal activity is the word "justitio" ${ }^{3}$ ), it was also interpreted as "resolving a conflict" or "applying established rules by a proper

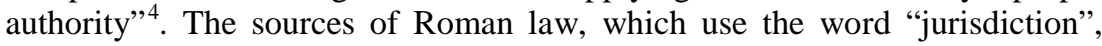
indicate that indeed the point was about a right backed by a power to make a judgment that was recognized as legitimate ${ }^{5}$. The echoy of the birth of jurisdiction could be found in the most ancient monuments of law: in the Hammurabi Laws and the Manu Laws - about punishment for contempt: the father and the priest, the judge and the representative of the ruling castes; in the Laws of the Dragon - about the power of the creditor; in the Book of Judges - about the power of judges; in the Laws of Swarga - about the power of kin and veche, etc. Ye. V. Vaskovskyy noted that "the jurisdictional way of protecting public and private interests should be regarded as the antithesis of self-government and revenge, to these wild types of justice" ${ }^{6}$.

In Modern times, there was a gradual separation of the judiciary from the public administration and an isolation of the law-enforcement function from the general administration first, and then, a division of the lawenforcement and the human rights functions of the state. Administrative procedures for the implementation of the human rights function in all their accessibility, coordination and efficiency, could not be applied due to the existence of hierarchical subordination of the supervised bodies to the supervisors. Therefore, for example, in France, where special administrative tribunals (the courts with special jurisdiction) were established for the first time in Europe, the terms "juridictionnel" ((jurisdictional) and "judiciair" ("that refers to court cases") differed. The former was used in relation to the

2 Кураков Л. Экономика и право: словарь-справочник. URL: http://vocable.ru/ dictionary/80/word/\%DE\%D0\%C8\%D1\%C4\%C8\%CA\%D6\%C8\%DF.

Денисенко В.В., Позднышов А.Н., Михайлов А.А. Административная юрисдикция органов внутренних дел: учебник. Москва: ИМЦ ГУК МВД России, 2002. 176 c. C. 5.

${ }_{4}$ Административная юрисдикция налоговых органов: учебник / Е.А. Алехин, Л.М. Ведерников, А.М. Воронов и др.; под ред. М.А. Лапиной. Москва: ВГНА Минфина России, 2012. 346 с. С. 25.

5 Реальный словарь классических древностей / под редакцией Й. Геффкена, Э. Цибарта. Тойбнер. Ф. Любкер. 1914. URL: http://dic.academic.ru/dic.nsf/ lubker/3776/ \%D0\%AE\%D0\%A0\%D0\%98\%D0\%A1\%D0\%94\%D0\%98\%D0\%9A\%D0\%A6\%D0\%98\% D0\%AF.

${ }^{6}$ Васьковский Е.В. Учебник гражданского процесса. Москва: Изд. бр. Башкамовых, 1914. 372 c. C. 2. 
activity of public law courts, the second was used concerning general courts that dealt with civil and criminal cases ${ }^{7}$.

In Ukrainian legal literature, the question of the nature of jurisdiction has been debated since the late 1960s, when there was a lively debate among domestic scholars about the nature of the phenomenon of jurisdiction in public administration. In particular, M.G. Alexandrov identified jurisdiction with the commission of law-enforcement activities ${ }^{8}$; S.S. Alekseev and V.M. Gorshenov considered it a kind of law-application activity ${ }^{9}$. N.G. Salishcheva proposed to distinguish between the jurisdiction of state and some public bodies in a narrow (law-permission activities) and in a broad (operational-executive activities) sense ${ }^{10}$.

In modern domestic law, in domestic and foreign doctrine and lawmaking, the category "jurisdiction" usually means "the right to exercise court", "cognizance", "the scope of the court", "the power to judge compulsory for the parties" 11 or the area to which such right applies. In this sense, jurisdiction is divided into two types: territorial, which is carried out within a specific territory - on land or in water spaces; personal, to which natural or legal persons are subject as a result of their citizenship or establishment ${ }^{12}$. With regard to maritime spaces (exclusive economic zone and continental shelf), "limited destination jurisdiction" is also distinguished ${ }^{13}$.

In the researches of the administrative-legal direction, "jurisdiction" is also considered as the activity of state-authorized bodies for the consideration of legal disputes arising in the state, which is conducted in strict accordance with the requirements of the law, as well as the possibility of applying to offenders measures of a compulsory nature ${ }^{14}$; a competent decision by

7 Зеленцов А.Б. Контроль за деятельностью исполнительной власти в зарубежных странах: учеб. пособ. Москва: Изд-во РУДН, 2002. 190 с. С. 67.

${ }_{8}^{8}$ Теория государства и права: учебник / Н.Г. Александров, Ф.И. Калинычев, А.В. Мицкевич, А.Л. Недавний и др.; отв. ред.: Н.Г. Александров. Москва: Юрид. лит., 1968. $640 \mathrm{c}$.

${ }_{9}$ Алексеев С.С. Общая теория социалистического права: Применение права. Наука права. Курс лекций: учеб. пособ. / ред.: Ю.К. Осипов, В.Е. Чиркин. Вып. 4. Свердловск: Сред.-Урал. кн. изд-во, 1966. 203 с.

${ }^{10}$ Салищева Н.Г. Гражданин и административная юрисдикция в СССР / отв. ред.: А.Е. Лунев. Москва: Наука, 1970. 164 с. С. 19-20.

11 Административное право зарубежных стран: учебник / И.Ю. Богдановская, С.Ю. Данилов, А.Б. Зеленцов, А.Н. Козырин и др.; под ред.: А.Н. Козырин, М.А. Штатина. Москва: Спарк, 2003. 464 с. С. 182.

${ }^{12}$ Спивакова Т.И. Проблема предела «национальной юрисдикции» на дне мирового океана в современном международном праве: автореф. дис. ... канд. юрид. наук. Москва, 1973. 20 c. C. 8.

${ }^{13}$ Мілаш В.С. Питання законодавчої юрисдикції держави в контексті регулювання договірних відносин у сфері електронної комерції. Право та інновації. 2015. № 1 . C. $42-49$. C. 43.

${ }^{14}$ Чернобай O.I. Теоретичні узагальнення щодо розуміння сутності поняття «адміністративна юрисдикція». Адміністративне право і процес. 2013. № 2. С. 61-67. С. 63. 
the competent authorities on various legal issues arising in the field of law ${ }^{15}$; the totality of the powers of the relevant state bodies to resolve legal disputes and offence cases [490, p. 26]; administration of justice or cognizance, as well as territorial boundaries of the competence of certain state or local selfgovernment bodies ${ }^{16}$.

In foreign jurisprudence and legislation, the term “jurisdiction” usually refers to cognizance, the right to administer justice, to resolve legal issues, and the scope of authority (including the territorial boundaries of such authority), the authority and competence of that authority ${ }^{17}$. In the English law system, "jurisdiction" is considered as "the practical power officially granted to a legally existing authority or political leader to make and publish decisions on legal issues, including to manage within its competence". The term is also used to refer to the geographical area or area to which these powers extend ${ }^{18}$, or to a church territory under the authority of a clergyman ${ }^{19}$. It also covers recognized rights as "the ability, right or authority to interpret and apply the law", "the power to administer or create laws", "the authority or right to exercise authority, exercise control", "the boundaries or territory over which those powers may be exercised" ${ }^{20}$.

In foreign countries of the continental legal family (Germany, France, Spain, Italy, Greece, Brazil), the jurisdiction is usually understood as: the implementation of the legal order; the power to apply the law in the particular case (as power, right and duty) arising from the sovereignty of the State, and the territory, geographical area (state, province, municipality, region, country) in which these powers are exercised or to which it extends sovereignty of the state, the limit of administrative competence of a state body.

Therefore, the foreign practice of using the investigated category indicates that it denotes the powers of the judiciary and public administration, as well as the spatial limits of their implementation. Its essence is defined as the right or process of exercising power, disclosed in detail either in the functions of the courts or in the administrative functions of public authorities to apply the rules of law and the interpretation of the rules of law. Thus, jurisdiction is the way of exercising public authority that is inherent in any social institution governed by the rules of law. It consists in the exclusive ability of a competent state or other authority to influence on subordinate

${ }^{15}$ Дружков П.С. О понятии и видах юрисдикции. Вопросы государства и права. Томск: Изд-во Том. ун-та, 1974. Т. 234. С. 81-89. С. 87.

${ }^{16}$ Ibid. C. $81-89$.

${ }^{17}$ Комлев С.В. Административно-юрисдикционный процесс: автореф. дис. ... канд. юрид. наук. Москва, 2008. 29 с. С. 13.

${ }_{18}$ Jurisdiction. URL: http://en.wikipedia.org/wiki/Jurisdiction.

${ }^{19}$ Definition of jurisdiction in English Turkish dictionary. URL: http://www.seslisozluk. $\mathrm{com} / \mathrm{search} /$ jurisdiction\#jurisdiction.

${ }^{20}$ Jurisdiction. URL: http://www.merriam-webster.com/dictionary/jurisdiction. 
persons in a certain territory legitimately and in the procedural forms established by the law ${ }^{21}$.

At the same time, given the general use of the category "jurisdiction", its definition has not yet been developed, but based on the views of domestic and foreign scientists, the results of the analysis of legislative practice, jurisdiction should be defined as the state activity carried out through the system of bodies authorized by it within their powers on exercising managerial influence (in its broadest sense as a manifestation of the legislative, executive and judicial power of the state in its entirety, and in some cases beyond) in the relationships that occur in a particular geographical area (for example, in marine areas).

In the legal literature it is stated that the jurisdiction of the state means the limits of the powers of the state and its bodies to issue laws (regulations), ensure compliance with and application of these acts. The state, in this sense, "defines the range of state bodies empowered to enforce the mentioned acts" ${ }^{22}$. O.S. Chernichenko defines jurisdiction as the ability of the state to ascribe or obey the rules of law, and as the right of the state to impose its power, and as the competence of the state to influence the behaviour of other entities, and as a legal authority ${ }^{23}$. It is only necessary to note that such activity is carried out by specially authorized by the state bodies and organizations.

The state exercises full jurisdiction within its territory and within some others, has limited jurisdiction. For example, a coastal state has jurisdiction over the exclusive economic zone for the establishment and use of artificial islands, installations and structures, marine scientific research, the protection and preservation of the marine environment, and also has sovereign rights for the exploration, development and conservation of the natural resources, whether living or non-living, in the waters superjacent to the seabed, the seabed and its subsoil, and for the purpose of managing of these resources, and with regard to other activities for the economic exploitation and exploration of the zone, such as the production of energy from the water, currents and winds (Art. 56 UNCLOS'82). The coastal state exercises over the continental shelf sovereign rights for the purpose of exploring it and exploiting its natural resources (Art. 77 UNCLOS'82), it also exercises exclusive jurisdiction over the creation and operation of artificial islands, installations and structures in this space (Article 80 of UNCLOS'82). According to J. Brownlee, the exercise

21 Кузурманова И.В. Административно-юрисдикционная деятельность органов исполнительной власти: содержание и системные характеристики: монография. Москва: ГУУ, 2012. 81 с. С. $17-18$.

22 Зябкин А.И. Несанкционированное вещание из открытого моря и международноправовые средства его пресечения: дис. ... канд. юрид. наук. Ленинград, 1985. 221 с. С. 121.

23 Черниченко О.С. Международно-правовые аспекты юрисдикции государств: автореф. дис. ... канд. юрид. наук. Москва, 2003. 31 с. 
of state jurisdiction is not completely detached from state territory, although it does not have a direct basis in the territorial rule ${ }^{24}$; he also notes that jurisdiction is regarded as one of the manifestations of sovereignty ${ }^{25}$.

V. Lowe defines the jurisdiction of the state according to the broad view as follows: "Jurisdiction" is a term that defines the limits of the legal competence of states or other governmental institutions (such as the EU) to create and apply legal rules governing the conduct of persons" ${ }^{26}$. A.R. Kayumova notes that the jurisdiction of the state is expressed in the ability of state bodies to exercise legal regulation of public relations and to ensure its observance through the application of the mechanism of state coercion $^{27}$. Thoroughly examining the genesis of the category "jurisdiction" in the legal literature of the last century, V.K. Kolpakov quite rightly states that after Ukraine gained the independence, this category should be explored in the light of new national legislation, which fills it with deeper content and gives reason to understand the jurisdiction as a legally formulated right of authorized bodies (officials) to exercise their functions concerning some objects $^{28}$. Indeed, Ukraine's legal framework for maritime activities indicates that the content of this legal category is contrast to the conventional points of view, which is exactly the way it is used in UNCLOS'82.

It is worth supporting the opinion of L.V. Terentyeva, who states that the study of jurisdiction in each of the domestic branches of legal science should not come apart from its understanding in international law, which is basic and defines the limits of the powers of the relevant state bodies ${ }^{29}$. And during the study of the jurisdiction of Ukraine in coastal waters, with the exception of inland waters, the UNCLOS'82 norms are the basic ones for understanding and determining the original content of all manifestations of public administration activities in such areas. Although at the time of the adoption of the Merchant Shipping Code of Ukraine ${ }^{30}$ and the Law of Ukraine "On the exclusive (maritime) economic zone of Ukraine" 31 UNCLOS'82 had not been ratified by Ukraine, compliance of these acts

${ }^{24}$ Броунли Я. Международное право: в 2 кн. / пер. с англ. Москва: Прогресс, 1977.

Кн. 2 / под ред.: Г.И. Тункин; пер. с англ. С.Н. Андрианов. 509 с. С. 369.

${ }^{25}$ Ibid. 535 c. C. 174.

${ }^{26}$ Evans M.D. International Law. Oxford University Press, 2003. 894 p. P. 329.

${ }^{27}$ Каюмова А.Р. К вопросу о месте юрисдикции в системе международного права. Ученые записки Казанского государственного университета. Серия «Гуманитарные науки». Казань: Изд-во Каз. гос. ун-та, 2007. Т. 149. Кн. 6. С. 316-323. С. 317.

${ }^{28}$ Колпаков В.К. Адміністративно-деліктний правовий феномен: монографія. Київ: Юрінком Інтер, 2004. 528 с. С. 378-380.

${ }^{29}$ Терентьева Л.В. Соотношение понятий «юрисдикция» и «суверенитет». Вестник Университета имени О.Е. Кутафина (МГЮА). 2016. № 12. С. 126-133. С. 137.

${ }_{30}$ Кодекс торговельного мореплавства України, 1995. Відомості Верховної Ради України. 1995. № 47. Ст. 349.

${ }^{31}$ Про виключну (морську) економічну зону України: Закон України від 16.05.1995 р. Відомості Верховної Ради Украӥни. 1995. № 21. Ст. 152. 
of Ukrainian legislation with its norms is undeniable. This tendency could be seen in Part 1 of Art. 9 CC of Ukraine ${ }^{32}$.

Thus, jurisdiction" means the exercise of powers by the state. This is the broadest understanding of "jurisdiction" - it is most relevant to the relations arising from the exercising of maritime activities, merchant navigation and inland navigation, and is relevant to the subject of this research.

Therefore, the category "jurisdiction" is multidimensional. Being used in various fields of law and legislation, with certain differences it signifies the exercise by the state authorized bodies of the whole complex of their powers in a certain territory and in a certain sphere of public relations. This involves establishing rules of conduct in a particular territory, assessing the state authorities' compliance with these rules of conduct by legal persons in terms of national law-and-order and internationally agreed norms that are binding on that state, applying legal sanction in the event of a negative result of such assessment, and also the application of other coercive measures of influence that are permissible under national law, as well as the implementation of service procedures in the spheres of government and authorized bodies within the designated area and in the waters. However, a final legislative interpretation of this category has not yet been developed.

According to most authors, jurisdiction is an independent type of state, by-law, law-enforcement, law-application activity, which has a competitive procedure for resolving a case, issuing a legal act in the form prescribed by law and the presence of a legal dispute (offense). However, not all researchers agree with the latter sign. Thus, I.V. Panova does not endorse "the views of some authors who believe that jurisdictional intervention by public authorities is not required until legal conflicts arise", and shares the opinion of "those who define jurisdiction as an activity of state, by-law, law-enforcement, lawapplication nature, which arises when it is necessary to apply measures of state coercion (the latter is not limited only by legal dispute), having a competitive nature, ends with the publication of a jurisdiction act and performs protective, educational and regulatory functions" ${ }^{33}$.

The researched scientific approaches to the definition of the essence of the categories "jurisdiction" and "jurisdiction of the state" testify to the present two directions in its understanding: as the reactions of the authorized bodies of the state to misbehaviour ("negative direction") and as the day-today activities of the authorized bodies of the authorities concerning administration in public life within the state territory, both land and water ("positive direction"). Here, however, it should be noted that with regard to

${ }^{32}$ Митний кодекс України, 2012. Офіиійний вісник Украӥни. 2012. № 32. Ст. 1175.

${ }_{33}$ Панова И.В. Об административной юрисдикции. Административная юрисдикция: материалы Всерос. науч.-практ. конф. / под ред. д-ра юрид. наук, проф. М.А. Лапиной. Москва, 2012. С. 28-32. 
the exercise of state jurisdiction in the face of state bodies in maritime spaces, its effect extends beyond the land, inland waters and territorial sea, and is "a manifestation of the state authoritative powers" ${ }^{34}$, carried out outside the state border of the country. This is confirmed both by the UNCLOS'82 norms and by the acts of its current and projected legislation of Ukraine, in particular the Law of Ukraine "On the exclusive (maritime) economic zone of Ukraine", the draft Law of Ukraine "On inland waters, territorial sea and contiguous zone of Ukraine". etc. Usually in these acts the category "jurisdiction" is used in the sense of extending the power of the state (represented by its bodies) to a certain space (maritime) or to installations, structures, artificial islands or vessels constructed in this space. Thus, the category of "jurisdiction" in domestic administrative law has a comprehensive character for determining the mechanism of activity in the coastal waters of the state, combines within the application of the relevant legislation a set of regulatory, prescriptive, prohibitive measures, as well as measures of administrative coercion, which in all cases make a legal regime of coastal water.

It should be noted that the greatest number of disputes arises when the category of jurisdiction is used to determine the extent of the rights of states with regard to water, primarily maritime, outside the state territory. If within the state territory the state itself has the right to establish the volume of rights in one or another sphere of activity, and the territory of the state is the sphere of its territorial supremacy, sovereignty exercised within those boundaries formed by a set of land, water and air parcels belonging to the composition of this state as a whole ${ }^{35}$, then, in the field of interstate relations, differences in the interpretation of the category "jurisdiction" lead to the fact that it is used both to denote the power of the state in areas where full sovereignty of the state is exercised, and to justify the rights of states to maritime spaces beyond their state borders.

With regards to maritime spaces, the category "jurisdiction" occupies a leading position in Roman law. V.E. Grabar stated: "The establishment of the jurisdiction of individual states at sea is carried out ... at the same time as the establishment of state political unions within the Roman Empire ... the jurisdiction which individual states within their territory have usurped within the empire extends from land to sea ...” ${ }^{36}$. L.A. Ivanaschenko considered that "jurisdiction" in the intelligence of ancient researchers meant the same thing

${ }^{34}$ Мілаш В.С. Питання законодавчої юрисдикції держави в контексті регулювання договірних відносин у сфері електронної комерції. Право та інноващії. 2015. № 1. С. 42-49. C. 43.

${ }^{35}$ Круглова И.А. Государство как субъект-носитель прав на суверенное воздушное пространство. Московский журнал международного права. 2005. № 3. С. 175-186. С. 178.

36 Грабарь В.Э. Римское право в истории международно-правовых учений. Элементы международного права в трудах легистов XII-XIV вв. Юрьев: Тип. К. Маттисена, 1901. 305 с. С. 218, 223. 
defined by the later term "sovereignty" ${ }^{37}$. The American Lawyer R. Young perceives no distinction between the categories of sovereignty and jurisdiction ${ }^{38}$. O'Connell's interpretation is very interesting: “Jurisdiction can be defined as a sovereign power over the rights of individuals by issuing laws, decrees and adjudicating matters"; in his opinion, it has different aspects: in the domestic aspect - it is complete sovereignty, in extraterritorial - sovereignty that extends as widely as international law allows. Therefore, full jurisdiction equates to sovereignty within state territory". Outside the state territory, according to O'Connell, the state also exercises jurisdiction but within the limits established by international law. As a result, O'Connell considers issues related to the modes of the high seas, territorial sea, continental shelf, etc. ${ }^{39}$, notably, all spaces where the state exercises only certain powers and rights.

In order to determine the legal scope of the category "jurisdiction", it seems appropriate to determine to which spaces and with what regime it may extend. The first question raised in 1967 by Malta about the need to regulate exploration and use of the bottom of the oceans was essentially a proposal to create a special regime for seabeds and oceans outside the jurisdiction of any state. The definition of jurisdiction given by the Maltese delegation was of a general nature: "National jurisdiction means the legal authority of a coastal State to control and regulate a particular area of the maritime space adjacent to its coast. It is subject to the restrictions provided for in the international law, which are intended to protect the interests of the international community" 40 . In this case, the terminological phrase "national jurisdiction" could refer to both the shelf and the territorial sea. It may also be recalled a provision contained in the 1990 Agreement between the USSR and the United States on the Maritime Space Line ${ }^{41}$ : "for the purposes of this Agreement, the term "coastal jurisdiction” means sovereignty, sovereign rights or any other form of jurisdiction over waters or seabed and subsoil that may be carried by a coastal State under international maritime law" (Article 5). Thus, it actually defines the forms of jurisdiction of the coastal state - sovereignty, sovereign rights and it is stated "any other form of jurisdiction", i.e. it is recognized the

${ }^{37}$ Иванащенко Л.А. Международно-правовой режим прибрежных морских вод: внутренних морских вод, территориальных вод и специальных морских зон: автореф. дис. ... канд. юрид. наук. Москва, 1952. 28 с.

${ }^{38}$ Young R. Resent Development with respect to the Continental Shelf. American Journal of International Law. 1948. № 4. P. 849-857.

${ }^{39}$ O’Connell D.P. International Law. Vol. II. London: Stevens, 1970. 714 p. P. 399, 601-602.

40 Доклад Комитета по мирному использованию дна морей и океанов за пределами действия национальной юрисдикции. Генеральная Ассамблея. Официальные отчеты. 26-я сессия. Нью-Йорк, 1971. Доп. № 21. А/8421.

${ }^{41}$ Agreement between the United States of America and the Union of Soviet Socialist Republics on the maritime boundary, 1 June 1990. URL: http://www.un.org/Depts/ los/LEGISLATIONANDTREATIES/PDFFILES/TREATIES/USA-RUS1990MB.PDF. 
possibility of expanding its manifestations. The latter further testifies to the "openness" of the category "jurisdiction of the state" and the possibility of its very broad interpretation.

States' competence over their territory is usually defined as sovereignty and jurisdiction; however, the categories used by legal sources are not uniform. The situation with the use of these categories is also not straightforward in legal science, since the numerous rights, duties, competences, privileges and immunities of states are often referred to "sovereignty and jurisdiction". The customary complex of state rights, the typical case of legal competence is generally referred to "sovereignty"; specific rights or a certain set of rights are quantitatively smaller than this complex, and are called "jurisdiction" 42 . Thus, "sovereignty" is a brief legal designation of the legal personality of a certain kind, namely the status of the state; "jurisdiction" also refers to specific aspects of such legal personality, especially with regard to rights (or claims), privileges and competence ${ }^{43}$. According to O'Connell's right expression, jurisdiction in the maritime expanses may "extend" beyond the territory of the State ${ }^{44}$. It is also noted that the jurisdiction of the state - the power of its legislative and judicial power can extend, and often enough extends beyond its borders ${ }^{45}$. According to Art. 24 of the Convention on the Territorial Sea and Contiguous Zone $1958^{46}$, the state recognizes the right to establish in the open sea a contiguous zone up to 12 nautical miles in which that state may exercise its jurisdiction in order to combat violations of its customs, fiscal, immigration or sanitary regulations, and has been extended to 24 nautical miles in accordance with UNCLOS'82 (Art. 33). In addition, in exclusive economic zones, coastal states have sovereign rights and exclusive jurisdiction over certain activities (Article 56 of UNCLOS'82, Article 11 of the Law of Ukraine "On the Exclusive (Maritime) Economic Zone of Ukraine"). The list of rules that establish the jurisdiction of the state outside the land territory can be continued.

It is necessary to maintain the view of S.O. Kuznetsov, who notes that the main issue in the study of the jurisdiction of the state in water, including coastal areas, is the question of the relationship between the categories of "jurisdiction" and "sovereignty". He notes that some authors attempt to combine the categories "territory" and "jurisdiction": "Territorial jurisdiction delineates the legal limits of the rule of law and the sphere of non-interference

\footnotetext{
${ }^{42}$ Verzijl J.H.W. International Law in Historical Perspective. Springer; 1 edition. P. 256.

${ }^{43}$ McNair A.D. International Law Opinions. Vol. I: Peace. Cambridge: Cambridge University press, 1956.380 p. P. 69-74

44 O’Connell D.P. International Law. Vol. II. London: Stevens, 1970. 714 p. P. 45.

45 Международное право: учебник / отв. ред. Ю.М. Колосов, Э.С. Кривчикова. Москва: Междунар. отнош., 2000. 720 с. С. 115.

${ }^{46}$ Конвенция о территориальном море и прилежащей зоне, 1958. Работа комиссии международного права. Изд. IV. Нью-Йорк: ООН, 1988. С. 174-183.
} 
in sovereign affairs by other states and international institutions” ${ }^{47}$. The scientist draws attention to certain remarks about the above thesis: first, "the limits of the supremacy of state authorities' acts" defines the state border (this so-called "territorial rule") ${ }^{48}$, second, the terminological phrase "territorial jurisdiction” defines a specific principle of jurisdiction (territorial or quasi-territorial) in view of the nationality of the territory withinwhich it (jurisdiction) is exercised ${ }^{49}$; third, the category of "jurisdiction" should be understood as "intervention" rather than "non-intervention". By establishing a defined law order in a particular part of the sea (zone, territory), UNCLOS'82 recognizes the right of coastal states to determine the special legal order for the stay and operation of vessels in so-called "Areas of National Jurisdiction": EEZ and surrounding areas (subject to their installation). No state has the right to subordinate any part of the high seas to its sovereignty, but the coastal state has the right to subordinate to its jurisdiction certain parts of the high seas ${ }^{50}$.

Indeed, in the surrounding area, the EEZ, on the continental shelf, the basis for exercising the jurisdiction of a coastal state is no longer the sovereignty of that state [as in inland waters and territorial sea (with respect to the latter, sovereignty is exercised in accordance with UNCLOS'82 and other international law (art. 2 UNCLOS'82) and can therefore be characterized as "maritime sovereignty"] but its international sovereign rights (EEZ, continental shelf, Art. 56, 77 UNCLOS'82) or international control rights in clearly defined areas - customs, fiscal immigration, sanitary (adjoining area, UNCLOS'82 Art. 33). S.V. Molodtsov confirms that, stating the jurisdiction is a warrant (authority) or a sum of warrants (powers) that have a purpose and do not necessarily have sovereignty, that is, jurisdiction is not always grounded or based directly on sovereignty ${ }^{51}$. V.L. Tolstykh also explicitly states that the coastal state in the EEZ has some sovereign rights, which are not based on territorial sovereignty and have a functional character ${ }^{52}$.

${ }^{47}$ Вихрист С.М. Імунітет та застосування юрисдикції в міжнародному кримінальному праві. Держава і право. 2001. Вип. 11. С. 500-503.

48 Про державний кордон України. Закон України від 04.11.1991 р. Відомості Верховної Ради Украӥни. 1991. № 2. Ст. 5.

49 Ключников Ю.В. Принципы осуществления предписывающей юрисдикции. Международное публичное и частное право. 2002. № 1. С. 11-17.

${ }^{50}$ Кузнецов С.О. Адміністративно-юрисдикційна компетенція України поза межами державного кордону. Актуальні проблеми держави $і$ права. 2004. Вип. 22: Матеріали 7-ї (59-ї) звіт. наук. конф. проф.-виклад. і аспірант. складу ОНЮА. Одеса, 2004. C. 505-510. C. 507.

${ }^{51}$ Молодцов С.В. Правовой режим морских вод. Москва: Междунар. отнош., 1982. 231 c. C. 28.

52 Толстых В.Л. Курс международного права: учебник. Москва: Волтерс Клувер, 2009. 1056 c. C. 894. 


\section{The concept of sovereign rights of states in maritime spaces}

The sovereign rights of states, first recognized and enshrined in UNCLOS'82, are currently one of the most relevant and under-researched aspects of the jurisdiction of states beyond their borders. The concept of the sovereign rights of a coastal state, which was particularly broadly supported during the 3rd United Nations Conference on the Maritime Law in determining the legal basis for the activity of States in maritime spaces beyond their national borders, is now embodied in UNCLOS'82. Its norms have become an alternative to the considerable claims of states to extend their sovereignty to offshore expanses of the sea, expressed in the mid-twentieth century. Indeed, the concept of sovereign rights has become a compromise solution to many of the problems faced by states that, thanks to the coastal waters, have been able to support their development and economic formation. In legal studies, sovereign rights of the state include those that ensure the economic independence of the state (to collect taxes and fees, energy resources, to develop natural resources and manage them), as well as to determine their competence, to enforce and pursue an independent foreign policy ${ }^{53}$.

Sovereign rights are the rights that a state has within its territory, bounded by national borders, and beyond, and that allow it to act in its interests to the extent it deems necessary, but within the limits of international law. Sovereign rights are determined by the basic principles of international law, international treaties of the state and its legislation. Such rights include the sovereign rights recognized and established in each coastal state in the EEZ and the continental shelf. The exclusive character of these rights is that no other state has the right without the consent of the coastal state to carry out such activities in these spaces.

There are certain restrictions on mentioned above sovereign rights, since the coastal state, in exercising its rights in the EEZ, takes into account the rights and obligations of other states and acts in accordance with the provisions of UNCLOS'82. In addition to maritime spaces, states have sovereign rights to exercise jurisdiction over ships, spacecraft and aircraft, if operated under its national flag. States have sovereign rights to explore and exploit outer space, the moon, the oceans, the Antarctic and other territories governed by the international community.

Sovereign rights cannot be identified with sovereignty, which is defined as the rule, autonomy, completeness and indivisibility of state power within its territory and as independence and equality in external relations. At the same time, the EMEZ of Ukraine and the continental shelf beyond the territorial sea, as well as the contiguous zone, are, in their essence, the open sea, where the coastal state has only internationally recognized agreements

53 Хаустова М.Г. Тенденції розвитку права в умовах глобалізації. Проблеми законності. 2013. Вип. 124. С. 3-15. С. 12. 
(which have become part of its national legislation in due course). These spaces are not the territory of Ukraine, so it is impossible to identify sovereignty and sovereign rights exercised outside the state territory. The jurisdiction of a coastal state in these territories is based not on sovereignty (as in inland waters and territorial sea), but rather on recognized and enshrined UNCLOS'82 sovereign rights. In legal literature, jurisdiction is defined as the realization (or possibility of realization) of sovereign rights of the state in relation to other subjects of law, it is designated as a manifestation of sovereignty and actions of state power within a certain territory. Its understanding as a manifestation of sovereignty cannot be considered fair for maritime spaces outside the territory of the state, since sovereignty is not exercised outside the territory of the state. Many definitions of sovereignty emphasize the overriding rule and independence of the state within its territory and with respect to other states ${ }^{54}$. S.V. Chernichenko notes that the sovereignty of the state is always "territorial", i.e. it exists within the territory of the state, and only its manifestations can go beyond its territory ${ }^{55}$. Indeed, its manifestations in the form of jurisdiction definitely go beyond the territory of the state in the exercise of extraterritorial or universal jurisdiction, but with respect to certain types of coastal maritime spaces, the jurisdiction of the state in them is not based on sovereignty, but on sovereign rights enshrined in international agreements, that cannot be identified with sovereignty because of it is much more general and inclusive, but only within the territory of the state. The spatial boundaries within which the sovereign rights and obligations of the modern state are exercised are wider than the geographical area within national borders, wider than the territories of the states.

I.A. Khavanova notes that, given the static and dynamic characteristics of the jurisdiction, it must be said that the completeness of its implementation may be limited beyond the territorial rule ${ }^{56}$. And this is quite fair, because, for example, in the contiguous zone, exclusive economic zone, on the continental shelf, the jurisdiction of the state is restricted by the rules of international agreements, in particular UNCLOS'82, which determine in what areas a coastal state may exercise its jurisdiction.

As Yu.G. Barsegov rightly points out, the jurisdiction of a coastal state is a set of limited functional rights of a coastal state in different regimes of the oceans. The category "jurisdiction" underpinning this concept is not strictly defined. If within the territorial rule, the national jurisdiction is a consequence and a manifestation of sovereignty, then outside the territorial sea it can be

${ }^{54}$ Кокошин А.А. Реальный суверенитет в современной микрополитической системе. Москва: Европа, 2006. 140 с. С. 47-57.

${ }_{55}$ Черниченко С.В. Делим ли государственный суверенитет? Евразийский юридический журнал. 2010. № 12. С. 25-31.

${ }^{56}$ Хаванова И.А. Налоговая юрисдикция: грани возможного и отсроченные риски. Журнал российского права. 2017. № 12. С. 81-91. С. 83. 
only limited functional jurisdiction of the coastal state in the form of clearly defined rights and prerogatives of resource and non-resource nature, established on the basis of international law and special international conventions of a universal nature. The scope of functional rights (jurisdictions) and the territorial boundaries of the coastal state's jurisdiction are determined, in particular, by UNCLOS' $82^{57}$.

Functional jurisdiction refers to the areas where international law allows states to exercise certain functional powers by exercising rights in areas such as the continental shelf and the EEZ; researchers note the following feature of this principle: if the sovereignty of the state requires the presence of power, subjects and territory, then the jurisdiction underpinning the functional principle takes place in the absence of state territory.

Yu. G. Barsegov also reasonably defines the zone of national jurisdiction as the spatial sphere of action of functional rights and the prerogatives or limited functional jurisdiction of both resource and non-resource content recognized by international law under the coastal state. Recognition of such rights and prerogatives of the coastal state is not considered as a basis for establishing any special status other than the status of the high seas (the expanses of which are the contiguous zone, EEZ, continental shelf). The decisive criterion for this approach is the fact that the sovereignty of a coastal state does not extend to areas of limited national jurisdiction ${ }^{58}$. These prerogatives are a kind of "compensation" to the coastal states for the restrictions they are subject to under UNCLOS'82 rule on the exercise of sovereignty in the territorial sea only in accordance with the provisions of this Convention and other rules of international law (Article 2), and form the settled principle of securing the rights of coastal states to certain prerogatives in the zones of national jurisdiction.

\section{CONCLUSIONS}

To summarize, it should be noted that the category "jurisdiction" is much narrower than the category of "sovereignty" and contains a limited range of rights, with an exact indication of the purpose for which the jurisdiction of this state extends to a given water area. In scientific research it is considered as follows: 1) the right to exercise the court, the sphere to which such right extends, 2) any powers exercised by the state within its territory, 3) the manifestation of sovereignty or sovereignty itself; 4) a category narrower than sovereignty, meaning certain conditioned rights, is a manifestation of sovereign rights. It is only necessary to emphasize that jurisdiction as a manifestation of the sovereignty of the state and the spatial boundary of the exercise of state power

57 Словарь международного морского права / отв. ред. Ю.Г. Барсегов. Москва: Междунар. отнош., 1985. 251 с. С. 250.

${ }^{58}$ Ibid. C. 66. 
should not be equated with it. It represents the exercise of power by the state, i.e. it can in fact be identified with the state power. In this regard, the actual recognition of jurisdiction as an element of sovereignty makes it possible to conclude that state authority is also an element of sovereignty. Meanwhile, state authority, being a derivative of "its" state, does not have sovereignty in itself, but is only conferred with certain powers in the person of the bodies exercising it. Sovereignty can be practically exercised through state authority, but it should not be identified with it ${ }^{59}$.

Thus, at present, the category "jurisdiction" is cross-sectoral and interdisciplinary and is used in the public and private branches of law and legal science. In each of them, its definition has its own specificity, but it always implements the idea laid down in Roman law of applying the rules established by the authorities, as well as the possibility of their establishment and implementation enshrined in the law (or custom). This has manifestation in defining the rules of conduct in a certain territory or in a certain water area, in the assessment and control by state bodies of their compliance by legal persons in respect to the national law and internationally agreed norms, the application of legal sanction and other coercive measures of influence in case of negative assessment result, as well as the implementation of service procedures in the spheres of administration by the state and its authorized bodies.

\section{SUMMARY}

In this article, the approaches to the definition and content of the legal categories "jurisdiction" and "sovereign rights" are discussed in the projection of relations emerging in the field of maritime activities. The development of the category "jurisdiction" since the first codified collections of legal norms was investigated. The classical positions of scientists concerning the content of this category are characterized. The norms of Ukrainian and foreign legislation, which define the content of the category "jurisdiction", are considered. The reasons and consequences of changing the content of this legal category for legal science and rulemaking practice are determined. It is summarized that today the category "jurisdiction" is cross-sectoral and interdisciplinary, it implements the idea laid down in Roman law of the application of the rules established by the authorities, as well as the possibility of their establishment and implementation enshrined in the law (or custom). In maritime areas under the sovereignty of a coastal state, jurisdiction is a manifestation of sovereignty, and in those where a coastal state has only sovereign rights, jurisdiction is a manifestation of these clearly defined and limited sovereign rights.

59 Терентьева Л.В. Соотношение понятий «юрисдикция» и «суверенитет». Вестник Университета имени О.Е. Кутафина (МГЮА). 2016. № 12. С. 126-133. С. 132. 


\section{REFERENCES}

1. Административная юрисдикция налоговых органов: учебник / Е.А. Алехин, Л.М. Ведерников, А.М. Воронов и др.; под ред. М.А. Лапиной. Москва: ВГНА Минфина России, 2012. 346 с. С. 25.

2. Административное право зарубежных стран: учебник / И.Ю. Богдановская, С.Ю. Данилов, А.Б. Зеленцов, А.Н. Козырин и др.; под ред.: А.Н. Козырин, М.А. Штатина. Москва: Спарк, 2003. 464 с.

3. Алексеев С.С. Общая теория социалистического права: Применение права. Наука права. Курс лекций: учеб. пособ. / ред.: Ю.К. Осипов, В.Е. Чиркин. Вып. 4. Свердловск: Сред.-Урал. кн. изд-во, 1966. $203 \mathrm{c}$.

4. Броунли Я. Международное право: в 2 кн. / пер. с англ. Москва: Прогресс, 1977 / под ред.: Г.И. Тункин; пер. с англ. С.Н. Андрианов.

5. Васьковский Е.В. Учебник гражданского процесса. Москва: Изд. бр. Башкамовых, 1914. 372 с.

6. Вихрист С.М. Імунітет та застосування юрисдикції в міжнародному кримінальному праві. Держава і право. 2001. Вип. 11. С. 500-503.

7. Грабарь В.Э. Римское право в истории международноправовых учений. Элементы международного права в трудах легистов XII-XIV вв. Юрьев: Тип. К. Маттисена, 1901. 305 с.

8. Денисенко В.В., Позднышов А.Н., Михайлов А.А. Административная юрисдикция органов внутренних дел: учебник. Москва: ИМЦ ГУК МВД России, 2002. 176 с.

9. Доклад Комитета по мирному использованию дна морей и океанов за пределами действия национальной юрисдикции. Генеральная Ассамблея. Официальные отчеты. 26-я сессия. Нью-Йорк, 1971. Доп. № 21. А/8421.

10. Дружков П.С. О понятии и видах юрисдикции. Bonpocы государства и права. Томск: Изд-во Том. ун-та, 1974. Т. 234. С. 81-89.

11.Зеленцов А.Б. Контроль за деятельностью исполнительной власти в зарубежных странах: учеб. пособ. Москва: Изд-во РУДН, 2002. $190 \mathrm{c}$.

12. Зябкин А.И. Несанкционированное вещание из открытого моря и международно-правовые средства его пресечения: дис. ... канд. юрид. наук. Ленинград, 1985. 221 с.

13. Иванащенко Л.А. Международно-правовой режим прибрежных морских вод: внутренних морских вод, территориальных вод и специальных морских зон: автореф. дис. ... канд. юрид. наук. Москва, 1952. 28 с.

14. Каюмова А.Р. К вопросу о месте юрисдикции в системе международного права. Ученые записки Казанского государственного университета. Серия «Гуманитарные науки». Казань: Изд-во Каз. гос. ун-та, 2007. Т. 149. Кн. 6. С. 316-323. 
15. Ключников Ю.В. Принципы осуществления предписывающей юрисдикции. Международное публичное и частное право. 2002. № 1. C. 11-17.

16. Кодекс торговельного мореплавства України, 1995. Відомості Верховної Ради України. 1995. № 47. Ст. 349.

17. Кокошин А.А. Реальный суверенитет в современной микрополитической системе. Москва: Европа, 2006. 140 с.

18. Колпаков В.К. Адміністративно-деліктний правовий феномен: монографія. Київ: Юрінком Інтер, 2004. 528 с.

19. Комлев С.В. Административно-юрисдикционный процесс: автореф. дис. ... канд. юрид. наук. Москва, 2008. 29 с.

20. Конвенция о территориальном море и прилежащей зоне, 1958. Работа комиссии международного права. Изд. IV. Нью-Йорк: ООН, 1988. С. 174-183.

21. Круглова И.А. Государство как субъект-носитель прав на суверенное воздушное пространство. Московский журнал международного права. 2005. № 3. С. 175-186.

22. Кузнецов С.О. Адміністративно-юрисдикційна компетенція України поза межами державного кордону. Актуальні проблеми держави i права. 2004. Вип. 22: Матеріали 7-ї (59-ї) звіт. наук. конф. проф.-виклад. і аспірант. складу ОНЮА. Одеса, 2004. С. 505-510.

23. Кузурманова И.В. Административно-юрисдикционная деятельность органов исполнительной власти: содержание и системные характеристики: монография. Москва: ГУУ, 2012. 81 с.

24. Кураков Л. Экономика и право: словарь-справочник. URL: http://vocable.ru/dictionary/80/word/\%DE\%D0\%C8\%D1\%C4\%C8\%CA\% D6\%C8\%DF.

25. Международное право: учебник / отв. ред. Ю.М. Колосов, Э.С. Кривчикова. Москва: Междунар. отнош., 2000. 720 с.

26. Митний кодекс України, 2012. Офічійний вісник Украӥни. 2012. № 32. Ст. 1175.

27. Мілаш В.С. Питання законодавчої юрисдикції держави в контексті регулювання договірних відносин у сфері електронної комерції. Право та інноваиії. 2015. № 1. С. 42-49.

28. Молодцов С.В. Правовой режим морских вод. Москва: Междунар. отнош., 1982. $231 \mathrm{c.}$

29. Панова И.В. Об административной юрисдикции. Административная юрисдикиия: материалы Всерос. науч.-практ. конф. / под ред. д-ра юрид. наук, проф. М.А. Лапиной. Москва, 2012. С. 28-32.

30. Пилипенко А. Адміністративно-юрисдикційна діяльність органів виконавчої влади: питання теорії. Право України. 2004. № 2. С. 26-31. 
31.Про державний кордон України. Закон України від 04.11.1991 р. Відомості Верховної Ради України. 1991. № 2. Ст. 5.

32. Про виключну (морську) економічну зону України: Закон України від 16.05.1995 р. Відомості Верховної Ради Украӥни. 1995. № 21. Ст. 152 .

33. Реальный словарь классических древностей / под редакцией Й. Геффкена, Э.Цибарта. Тойбнер. Ф. Любкер. 1914. URL: http://dic. academic.ru/dic.nsf/lubker/3776/\%D0\%AE\%D0\%A0\%D0\%98\%D0\%A1\% D0\%94\%D0\%98\%D0\%9A\%D0\%A6\%D0\%98\%D0\%AF.

34. Салищева Н.Г. Гражданин и административная юрисдикция в СССР / отв. ред.: А.Е. Лунев. Москва: Наука, 1970. 164 с.

35. Словарь международного морского права / отв. ред. Ю.Г. Барсегов. Москва: Междунар. отнош., 1985. 251 с.

36. Спивакова Т.И. Проблема предела «национальной юрисдикции» на дне мирового океана в современном международном праве: автореф. дис. ... канд. юрид. наук. Москва, 1973. 20 с.

37. Теория государства и права: учебник / Н.Г. Александров, Ф.И. Калинычев, А.В. Мицкевич, А.Л. Недавний и др.; отв. ред.: Н.Г. Александров. Москва: Юрид. лит., 1968. 640 с.

38. Терентьева Л.В. Соотношение понятий «юрисдикция» и «суверенитет». Вестник Университета имени О.Е. Кутафина (МГЮА). 2016. № 12. С. 126-133.

39. Толстых В.Л. Курс международного права: учебник. Москва: Волтерс Клувер, 2009. 1056 с.

40. Хаванова И.А. Налоговая юрисдикция: грани возможного и отсроченные риски. Журнал российского права. 2017. № 12. С. 81-91.

41. Хаустова М.Г. Тенденції розвитку права в умовах глобалізації. Проблеми законності. 2013. Вип. 124. С. 3-15.

42. Черниченко О.С. Международно-правовые аспекты юрисдикции государств: автореф. дис. ... канд. юрид. наук. Москва, 2003. 31 с.

43. Черниченко С.В. Делим ли государственный суверенитет? Евразийский юридический журнал. 2010. № 12. С. 25-31.

44. Чернобай O.I. Теоретичні узагальнення щодо розуміння сутності поняття «адміністративна юрисдикція». Адміністративне право i прочес. 2013. № 2. C. 61-67.

45. Agreement between the United States of America and the Union of Soviet Socialist Republics on the maritime boundary, 1 June 1990. URL: http://www.un.org/Depts/los/LEGISLATIONANDTREATIES/PDFFILES/ TREATIES/USA-RUS1990MB.PDF.

46. Convention on the Law of the Sea, 1982. The official website of UN. URL: http://www.un.org/depts/los/convention_agreements/texts/unclos/ unclos_e.pdf. 
47. Definition of jurisdiction in English Turkish dictionary. URL: http://www.seslisozluk.com/search/jurisdiction\#jurisdiction.

48. Evans M.D. International Law. Oxford University Press, 2003. 894 p.

49. Jurisdiction. URL: http://en.wikipedia.org/wiki/Jurisdiction.

50. Jurisdiction. URL: http://www.merriam-webster.com/dictionary/ jurisdiction.

51. McNair A.D. International Law Opinions. Vol. I: Peace. Cambridge: Cambridge University press, 1956. 380 p.

52. O’Connell D.P. International Law. Vol. II. London: Stevens, 1970. $714 \mathrm{p}$.

53. Verzijl J.H.W. International Law in Historical Perspective. Springer; 1 edition

54. Young R. Resent Development with respect to the Continental Shelf. American Journal of International Law. 1948. № 4. P. 849-857.

\section{Information about the authors:}

Fedotov O. P.,

Doctor of Law Sciences, Professor of the Department of Maritime and Customs Law,

National University "Odessa Law Academy"

23, Fontanska Doroga, Odesa, 65000, Ukraine

Averochkina T. V.,

Doctor of Law Sciences, Assistant Professor,

Head of the Laboratory of the Department of Maritime and Customs Law,

National University "Odessa Law Academy”

23, Fontanska Doroga, Odesa, 65000, Ukraine 